\title{
Las organizaciones del trabajo y su impacto en las condiciones físicas y psicosociales de los trabajadores
}

Figueroa V. Maria Eugenia.

\begin{abstract}
- Resumen
La ergonomía como disciplina científica que pretende adaptar las exigencias de la actividad a las características de las personas, ha sido utilizada en este trabajo para el análisis de una organización del trabajo tradicional, un sistema de producción en masa y un representante de las nuevas organizaciones del trabajo, sistema Just in Time, las células de producción. Este estudio recoge los principios por los que la actividad laboral debe ser revalorizada por la sociedad, y propone mediante la comparación, que esta organización del trabajo desarrollada por los japoneses, además de lograr los objetivos productivos para los que fue propuesto, disminuye el riesgo de enfermedades de etiología ocupacional y entrega mejores niveles de satisfacción en los trabajadores.
\end{abstract}

\begin{abstract}
The ergonomics, as scientific discipline, which pretends to adapt the challenge of the activity to the characteristics of the persons, has been used for the analysis of a traditional work organization, a mass production system, and a representative of the new work organizations, Just in Time system - the production cells. This study retatake the principles through wich the labor activity must be revalued from the society and propase througout a comparision, that this work organization system developed by the japanes, beside meeting the productive goals for wich was designed, decrece the risk of occupational deseases and gives better levels of satisfaction for workers.
\end{abstract}

Contacto $>>$ Escuela de Terapia Ocupacional. Facultad de Medicina. Universidad de Chile. Av. Independencia 1027. Santiago de Chile 